\title{
Age Factor in Business Education Students' Use of Social Networking Sites in Tertiary Institutions in Anambra State, Nigeria
}

\author{
Ementa, Christiana Ngozi ${ }^{1} \&$ Ile, Chika Madu ${ }^{1}$ \\ ${ }^{1}$ Department of Vocational Education, Nnamdi Azikiwe University, Nnamdi Azikiwe University, Awka, Nigeria \\ Correspondence: Ementa, Christiana Ngozi, Department of Vocational Education, Nnamdi Azikiwe University, \\ Nnamdi Azikiwe University, Awka, Nigeria. E-mail: cn.ementa@unizik.edu.ng
}

Received: August 19, 2015

Accepted: September 15, 2015

Online Published: September 17, 2015

doi:10.5430/ijhe.v4n4p113

URL: http://dx.doi.org/10.5430/ijhe.v4n4p113

\begin{abstract}
There are diverse social networking sites which range from those that provide social sharing and interaction to those that provide networks for professionals within same and other fields. Social networking sites require a user to sign up, create a profile and begin sending short messages about what the user is doing or thinking. The study sought to establish from business education students in tertiary institutions in Anambra state Nigeria, hours of the day spent on social networking sites, social networking sited used and what they use social networking site for. Relevant theories and literature were reviewed. Population of the study was made up of 577 penultimate and final year business education students of four tertiary institutions in Anambra state. Proportionate sampling technique was used to select 236 students for the study. Three hypotheses guided the study. A structured questionnaire was used to gather information for the study. The data collection instrument was subjected to a reliability test which yielded a reliability coefficient of 0.80 using Cronbach alpha. Analysis of Variance (ANOVA) was used to test the hypotheses at $95 \%$ confidence interval. Findings revealed that business education students differed significantly on hours of the day spent using social networking sites and on what they use social networking sites for, but do not differ significantly on social networking sites they use as a result of age. Consequently, it was recommended, among others, that business education students of all age brackets should be taught to harness the educational potentials of social networking sites so as to effectively use these sites for educational purposes.
\end{abstract}

Keywords: Age factor, Business education students, Social networking sites

\section{Introduction}

The internet has changed the manner individual members of the society associate, interact and communicate. Individuals define their social and communal life through the internet and become members of social networks to connect with people of similar field of interest, culture and background. Social networking sites are internet enabled platforms that permit people to express themselves and actively participate in the creation and dissemination of information. Social networking sites are platforms for virtual social lives created by people over the internet (Tiryakioglu \& Erzurum, 2011). Social networking sites as defined by Boyd and Ellison (2007) are a web-based service that allows individuals to:

a. Construct a public or semi-public profile within a branded system

b. Articulate a list of other users with whom they share a connection and

c. View and transverse their list of connections and those made by others within the system.

Social networking sites offer individuals the possibilities of networking and sharing media content, and embrace the main Web 2.0 attributes against the framework of their respective structural characteristics (Jenkins, 2006). Social networking sites are websites that offer a wide variety of resources and services. These sites include: Facebook, Twitter, MySpace, LinkedIn, YouTube, WhatsApp, Badoo, Friendster, 2go, Skype, BBM, WeChat, Viber and so on. Features of social networking sites according to Oluwalanu, Omowale and Okunade (2014) are that it affords the user:

a. Participation that encourages users to add value to the application as they use through the edit box interface.

b. Opportunity to exercise control on the data.

c. Interaction on a more advanced software level, giving access to previously unavailable digital content. 
d. Create the web by socializing and gradually moving members from the physical world to the online world.

Oluwalanu, Omowale and Okunade (2014) further noted that there are different social networking sites ranging from those that provide social sharing, to those that provide networks for professionals within same field, or to interact with other professionals in other fields. The networks require users to sign up, create a profile, and begin sending short messages about what they are doing and thinking. Quan-Haase and Young (2010) noted that the satisfaction received from social networking sites help users feel that they are part of a peer network of knowing what was going on about events and activities. Social networking sites therefore enable people to be 'on the know' of daily events.

\subsection{Statement of the Problem}

There are different social networking sites, varying from those that provide social sharing, to those that provide social networks for professionals within same field and professionals in other fields. Teenagers and young adults are attracted to the use of social networking sites which they use to link, connect and share common interest. Business education students in tertiary institutions like other students, make use of social networking sites for diverse purposes which range from viewing friends pictures to chatting (Ementa \& Ile, 2014). Business education students are vocational education students in universities and colleges of education who are taught skills for effective performance in the business world and for teaching. In Nigeria, and Anambra state in particular, there seem to be no empirical evidence as to age being a factor in business education students' use of social networking sites, therefore this study.

\subsection{Purpose of the Study}

The main purpose of this study is to ascertain the influence of business education students use of social networking sites in tertiary institutions in Anambra state, Nigeria. Specifically, the study sought to find out if;

1. Age has any influence on the number of hours of the day business education students spend on social networking sites.

2. Age has influence on social networking sites business education students use most.

3. Age of students determine what business education students use social networking sites for.

\subsection{Hypotheses}

The following null hypotheses were tested at 0.05 level of significance.

1. There is no significant difference in business education students mean rating of hours of the day spent on social networking sites as a result of age.

2. There is no significant difference in business education students rating of social networking sites used as a result of age.

3. There is no significant difference in what business education students use social networking sites for as a result of age.

\section{Literature Review}

Social networking sites are important tools for sharing and obtaining new information. Young people and students often referred to as 'digital natives' are the ardent users of social networking sites. Scholars have conducted research as to what use students put social networking sites. Lenhart, Madden, Macgill and Smith (2007) in a study of 935 participants in USA revealed that teens aged 12-17 use social networking sites to stay in touch with friends and to make new friends. The writers further reported that students visit their social networking sites at least once a day.

In a similar study to ascertain students' use of social networking sites as regards to age, Mikami, Szwedo, Allen, Evans and Hure (2008) used a longitudinal sample of 92 students and examined young adults communication on social networking websites and reported that students aged $13-14$ used social networking sites more than those aged 20-23. Khan (2011) conducted a study in Pakistan on impact of social networking sites on students and recounted that students aged 15-25 used social networking sites for entertainment. Poellhuber, Normand and Anderson (2011) conducted a study in Canada to ascertain students' readiness for social media and collaboration and found that students aged 16-24 use social networking sites for social and entertainment purposes while older students understood what social networking sites offer and were interested in using them for learning.

EDUCAUSE Center for Applied Research (2008) carried out a research on students in tertiary institutions in USA to ascertain students use and time spent in the use of social networking sites and reported that younger students spend more time using social networking sites than older students. They also found that younger students preferred 
Facebook to MySpace while older students preferred the use of MySpace. Olowu and Seri (2012) conducted a study of social networking sites addiction of 884 tertiary education students in Oyo state, Nigeria and reported that students between the ages of 16 and 30 spent a lot of time on social networking sites and the students were addicted to the use of these sites.

\subsection{Theoretical Framework}

Students' use of social networking sites is influenced by a diverse factor among which is age. Age factor in individuals' use of social networking sites could be understood by reviewing certain theories. For instance, the theory of uses and gratification propounded by Katz, Blumber and Gurevitch in 1974. It is a communication theory based on five assumptions, which provides a framework understanding the relationship between the media and the viewers, and how the audience is more or less active in the use of media and the end result of their participation. This theory believes that users intentionally choose media that will satisfy given needs and allow individuals to enhance knowledge, relaxation, diversion of thought or social interactions. This theory is an approach towards an understanding of how and why people seek out specific media to satisfy specific purposes.

Second instance is the unified theory of acceptance and use of technology developed by Ventakesh, Moris, Davis and Davis in 2003. This theory proposes that performance expectancy, effort expectancy and social influence predict behavioural intentions toward the acceptance of technology. Additionally, the theory stated that facilitating conditions and behavioural intention predicts use behaviour in acceptance of technology while gender, age, education and voluntariness of use are fundamental moderating influence on behaviour. In this theory, age is a key factor as it moderates performance expectancy (degree to which an individual believes that using a system will help him or her to attain gains in job performance), effort expectancy (degree of ease associated with the use of the system), social influence (degree to which an individual perceives that an important other believes he or she should use the new system) and facilitating condition (degree to which an individual believes that an organizational and technical infrastructure exists to support use of the system) to predict or indicate behavioural intention and use behaviour. Age therefore is a key factor that predicts individuals' intention and use of a technology.

Both theories view an individual as a choice making user of a media and age as a factor in the intention and use of social networking sites.

\section{Method}

The design adopted for the study was descriptive survey research design. Osuala (2004) recommended that survey research design is most appropriate for studies which center on individuals and their opinions, beliefs, motivation and behaviour. The study was conducted in Anambra state which is located in the south east Nigeria. The population of the study comprised 577 penultimate and final year business education students in four tertiary institutions (universities and colleges of education) namely: Nnamdi Azikiwe university, Awka (199 students); Madonna University, Okija (17 students); Federal College of Education (technical), Umunze (295 students) and Nwafor Orizu College of Education, Nsugbe (66 students). Proportionate sampling was used to select 236 students from the tertiary institutions thus: Nnamdi Azikiwe University, Awka (81 students); Madonna University, Okija (7 students); Federal College of Education (Technical), Umunze (121 students) and Nwafor Orizu College of Education, Nsugbe (27 students). A structured questionnaire with 23 items altogether in three clusters (B1, B2 and B3) was used for data collection. Out of the 236 copies administered, one hundred and ninety five copies were correctly completed and found useful for data analysis. Data collected were analyzed using Analysis of Variance (ANOVA). In testing the hypotheses, where p-value of paired t-test is greater than 0.05 , it means that there is no significant difference in the respondents' opinions and the hypothesis will be accepted. Conversely, where the p-value of paired t-test is less than 0.05 , it means that there is significant difference in the respondents' opinions and the hypothesis will not be accepted.

\section{Results}

The results of the study are presented below;

Hypothesis 1: There is no significant difference in business education students rating of hours of the day spent on social networking sites as a result of age. 
Table 1. Summary of Analysis of Variance (ANOVA) on response of business education students in four tertiary institutions on hours of the day spent on social networking sites based on age

\begin{tabular}{lcclccc}
\hline $\begin{array}{l}\text { Sources } \\
\text { Of Variance }\end{array}$ & $\begin{array}{c}\text { Degree of } \\
\text { Freedom }\end{array}$ & $\begin{array}{l}\text { Sum of } \\
\text { Squares }\end{array}$ & $\begin{array}{l}\text { Mean } \\
\text { Squares }\end{array}$ & F-Cal & P.Value & Remarks \\
\hline Between Groups & 2 & 2.56 & 1.28 & \multirow{2}{*}{29.10} & 0.00 & Significant \\
Within Groups & 27 & 1.19 & 0.04 & & Difference \\
Total & 29 & 3.74 & & & \\
\hline
\end{tabular}

$\begin{array}{llll}\text { Age Variable } & \mathrm{N} & \text { Mean } & \text { SD } \\ 15-20 & 10 & 1.52 & 0.25 \\ 21-26 & 10 & 1.28 & 0.18 \\ \text { Above 26 } & 10 & 0.81 & 0.20\end{array}$

Individual 95\% Confidence Interval for Mean based on pooled Standard deviation

$\mathrm{SD}$

0.25

0.20

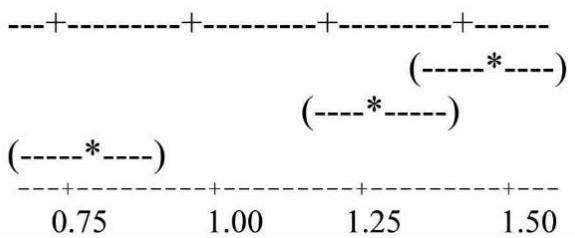

Data in Table 1 reveals the responses of business education students on hours of the day spent on social networking sites with p-value at 0.00 which is less than 0.05 . This shows that there is a significant difference in the ratings of business education students on hours of the day spent on social networking sites as a result of age. The chart shows the responses from students aged 15 to 20 was not significantly different from those aged 21 to 26 but students above 26 years significantly differed from both.

Hypothesis 2: There is no significant difference in business education students rating of social networking sites used as a result of age.

Table 2. Summary of Analysis of Variance (ANOVA) on the response of business education students in four tertiary institutions on social networking sites used based on age

\begin{tabular}{lcccccc}
\hline Sources & $\begin{array}{c}\text { Degree of } \\
\text { Freedom }\end{array}$ & $\begin{array}{c}\text { Sum of } \\
\text { Squares }\end{array}$ & $\begin{array}{c}\text { Mean } \\
\text { Squares }\end{array}$ & F- Cal & P.Value & Remarks \\
\hline Between Groups & 2 & 0.04 & 0.02 & 0.31 & 0.74 & $\begin{array}{l}\text { No Significant } \\
\text { Within Groups }\end{array}$ \\
& 24 & 1.51 & 0.06 & & & \\
Total & 26 & 1.55 & & & & \\
\hline
\end{tabular}

$\begin{array}{lllr}\text { Age Variable } & \text { N } & \text { Mean } & \text { SD } \\ 15-20 & 9 & 1.27 & 0.23 \\ 21-26 & 9 & 1.32 & 0.25 \\ \text { Above } 26 & 9 & 1.36 & 0.26\end{array}$

Individual 95\% Confidence Intervals for mean based on pooled standard deviation

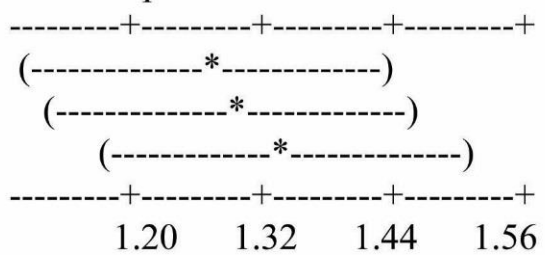

Data in Table 2 reveals the responses of business education students on social networking sites business education students use with p-value at 0.74 which is greater than 0.05 . This shows that there is no significant difference in business education students' ratings of social networking sites used as a result of age. The chart also shows that there is no significant difference in the response of business education students as a result of age.

Hypothesis 3: There is no significant difference in the mean ratings of business education students on what business education students use social networking sites for based on age. 
Table 3. Summary of Analysis of Variance (ANOVA) on the response of business education students in four tertiary institutions on what business education students use social networking sites for based on age

\begin{tabular}{lcccccc}
\hline Sources & $\begin{array}{c}\text { Degree of } \\
\text { Freedom }\end{array}$ & $\begin{array}{l}\text { Sum of } \\
\text { Squares }\end{array}$ & $\begin{array}{c}\text { Mean } \\
\text { Squares }\end{array}$ & F-Cal & P.Value & Remarks \\
\hline $\begin{array}{l}\text { Between } \\
\text { Groups }\end{array}$ & 2 & 0.72 & 0.36 & & & \\
$\begin{array}{l}\text { Within } \\
\text { Groups } \\
\text { Total }\end{array}$ & 30 & 6.72 & 0.22 & 1.61 & 0.01 & $\begin{array}{c}\text { Significant } \\
\text { difference }\end{array}$ \\
\hline
\end{tabular}

$\begin{array}{llll} & & & \\ & & & \\ \text { Age variable } & \mathrm{N} & \text { Mean } & \text { SD } \\ 15-20 & 11 & 3.15 & 0.62 \\ 21-26 & 11 & 3.38 & 0.41 \\ \text { Above 26 } & 11 & 3.51 & 0.37\end{array}$

Individual 95\% Confidence Intervals for mean based on pooled standard deviation

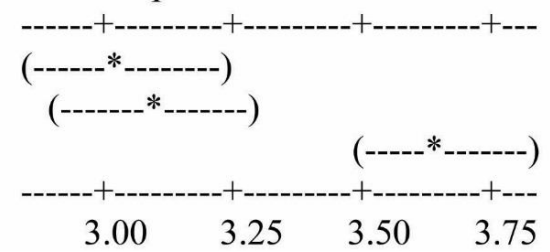

Data in Table 3 reveals the response of business education students on what business education students use social networking sites for with p-value at 0.01 which is less than 0.05 . This shows that there is a significant difference in business education students' ratings of what they use social networking sites for as a result of age. The chart also shows that there is a significant difference in the response of business education students as students aged 26 and above differs from students aged 15 to 20 and 21 to 26 .

\section{Discussion}

The findings in Table 1 revealed that business education students differed in hours of the day they spend on social networking sites based on their age. Students aged 26 years and above differed significantly from students aged between 15 to 20 and 21 to 25. This finding supports the findings of Poellhuber, Mormand and Anderson (2011) who reported that older students spend less time in the use of social networking sites than younger students. The finding also supports the finding of EDUCAUSE Center for Applied Research (2008) which reported that younger students spend more time on social networking sites than older students. The implication of this finding is that older business education students spend less time in the use of social networking sites than younger students.

The findings in Table 2 showed that business education students did not differ in social networking sites used as a result of age. This finding is at variance with the findings of FactBound Research (2011) which reported that adults aged 26-33 years prefer the use of Facebook. The finding is also in disagreement with the findings of EDUCAUSE Center for Applied Research (2008) which found that students aged 18 to 24 years use Facebook while older students use MySpace. This finding implies that business education students irrespective of age use social networking sites for varying purposes which range from communicating to socializing.

The findings in Table 3 revealed that business education students differed significantly in what they use social networking sites for. This finding is in agreement with the findings of Poellhuber, Mormand and Anderson (2011) who reported that older students use social networking sites for learning more than younger students. This implies that older business education students use social networking sites for educational purposes more than younger students.

\section{Conclusion}

From the findings of the study, it is concluded that business education students above 26 years of age use social networking sites with educational potentials and use them for academic purposes more than students aged 15 to 20 and 21 to 26 years. Also, students between 15 to 20 and 21 to 26 years spend a lot of hours of the day using social networking sites for different purposes other than academic purposes more than students above 26 years. This could be because older students are mature adults who are engaged in diverse activities which expend their time. 


\section{Recommendations}

Based on the findings of this study and conclusion drawn, the following recommendations were made:

1. Business education students irrespective of age should show greater interest in the use of social networking sites for academic purposes so as to effectively harness and utilize the educational advantages which these sites present to their users.

2. The Association of Business Educators of Nigeria (ABEN) should train lecturers through conferences and symposia on how to acquire skills and competencies needed to effectively use social networking sites in the teaching and learning process. This will in turn, encourage students to appreciate the need for such sites and use them for academic purposes.

3. Management of tertiary institutions should organize workshops for lecturers on how to use facilities in social networking sites such as instant messaging, chat rooms and so on, for submission of term papers, assignments and collaborative research works. This will have a spill-over effect on the academic upbringing of the students.

4. Management of tertiary institutions should organize seminars to educate students on how they can effective and efficiently manage their time and make productive use of social networking sites for academic goals. Armed with this knowledge, the students will learn to make better use of the various networking sites to improve themselves and connect to people and organizations that will make positive impact in their lives.

\section{References}

Boyd, D., \& Ellison, N. (2007). Social network sites: Definition, history and scholarship. Journal of Computer-Mediated Communication, 13(2), 68-73. http://dx.doi.org/10.1111/j.1083-6101.2007.00393.x

EDUCAUSE Center for Applied Research (2008). Social networking sites. Students and Information Technology, ECAR Research Study, 8, 81 -98.

Ementa, C. N., \& Ile, C. M. (2014). Business education students' perception of social networking sites in tertiary institutions in Anambra state. Paper presented on $26^{\text {th }}$ annual conference of Association of Business Educators of Nigeria at Kwara State University, Malete from $14^{\text {th }}-18^{\text {th }}$ October.

FactBound Research (2011). Social Media: Assessing the level of social media consumption and usage among Nigerian adults. Retrieved from www.mmccgroup.com

Jenkins H. (2006). Where old and new media collide. New York: Convergence culture.

Kahn, S (2012). Impact of social networking websites on students. Abasyn Journal of Social Sciences, 5 (2), 56-77.

Katz, E; Blumler \& Gurevitch, M. (1974). Uses of mass communication by individual. In Davidson, W. P \& Fredrick, Y. (Eds), Mass Communication Research: Major Issues and Future Directions. (pp. 11-35). New York: Praeger.

Lenhart, A, Madden, M, Macgill, A. R. \& Smith, A. (2007). Teens and social media. Retrieved from http://www.pewinternet.org/2007/PIP_Teens_Social_Media_Final.

Mikami, A.Y.; Szwedo, D. E.; Allen, J. P.; Evans, M. A. \& Hure, A. L. (2010). Adolescent peer relationships and behaviour problems predict young adults' communication on social networking websites. Developmental Psychology, 46(1), 46-56. http://dx.doi.org/10.1037/a0017420

Olowu, A. O; \& Seri, F. O. (2012). A study of social network addiction among youths in Nigeria. Journal of Social Science and Policy Review, 4, $62-71$.

Oluwulanu, S. B; Omowale, A. \& Okunade, J. K (2014). Adapting social media for formal learning in Nigeria: Challenges and prospects. Arabian Journal of Business and Management Review, 3 (9), 22 - 30.

Osuala, E. C. (2004). Foundations of vocational education. Enugu: Cheston Publishers.

Poellhuber, B; Normand, B \& Anderson, T. (2011). Distance students readiness for social media and collaboration. Retrieved from http://www.irrodl.org/index.php/irrodl/article/view/1018/1960

Quan-Haase, A., \& Young, A. L. (2010). Uses and gratifications of social media: A comparison of facebook and instant messaging. Bulletin of Science, Technology \& Society, 30(5), 350-361. http://dx.doi.org/10.1177/0270467610380009

Tiryakioglu, F \& Erzurum, F. (2011). Use of social networks as an education tool. Contemporary Educational Technology, 2(2), 135-150.

Ventatesh, V. M; Davis, F. D \& Davis, G. B. (2003). User acceptance of information technology: Toward a unified view. MIS Quarterly, 27, 425 - 478. 